\title{
THE CONCEPT OF NEMESIS IN PSYCHONEUROSIS
}

\author{
A.H. CHAPMAN*, MIRIAM CHAPMAN-SANTANA*, DJALMA VIEIRA E SILVA*
}

\begin{abstract}
A patient who has a nemesis fear as the basic process in his psychoneurosis feels that he is destined to repeat the life course of one of his parents to eventual long-term psychosis, or incapacitating physical illness or death by illness or accident. He feels that this will occur at about the same age as that at which his parent suffered his misfortune. The patient during his childhood and adolescence had a traumatic relationship with this parent, and is haunted by guilt feelings about it, and fears that avenging destiny, or nemesis, requires that he pay with a similar misfortune for that which he feels he caused. These patients improve much in psychotherapy, but the underlying nemesis fear, though much reduced in severeity, is not entirely eliminated.
\end{abstract}

KEY WORDS: psychoneurosis, obsession, psychotherapy.

\section{O conceito de nêmesis em psiconeurose}

RESUMO - Os pacientes que tenham um sentimento de "nêmesis" como processo básico em suas psiconeuroses, têm medo de que estejam destinados a reproduzir, em suas existências, acontecimentos que ocorreram na vida de um de seus pais. Eventualmente, temem terminar com uma psicose duradoura, ou com uma doença física incapacitante, ou com morte por doença, ou com um acidente. Acham que esses eventos vão ocorrer, aproximandamente, na mesma idade em que seu pai ou sua mãe sofreram seu infortúnio. Os pacientes, durante sua infância e adolescência, tiveram uma convivência traumática com seu pai ou com sua mãe e passaram a nutrir fortes sentimentos de culpa no que diz respeito a esse relacionamento turbulento e desenvolveram o medo de que as forças de um destino vingativo, ou "nêmesis", exijam que eles paguem com o mesmo tipo de infortúnio pela calamidade que acreditam ter causado a seu pai ou sua mãe. Esses pacientes melhoram muito com a psicoterapia, mas o sentimento de "nêmesis", o medo básico, ainda que muito reduzido, não é eliminado completamente.

PALAVRAS-CHAVE: psiconeurose, obsessão, psicoterapia.

\section{THE CHARACTERISTICS OF NEMESIS FEARS}

The central core of some psychoneurotic disorders is a persistent, anxiety-ridden conviction in the patient that he or she is destined to repeat the life course of one of his parents to a tragic end. For example, a patient may fear that he will die of heart disease at about the same age as that at which his father died, or that he will at some particular time in his life become psychotic for a similar basic reason ${ }^{2}$.

Such a feeling is a nemesis fear. Nemesis was in Greek mythology the goddess of avenging destiny, or avenging justice; she punished individuals, or at times whole communities, for wrongs they had committed by inflicting on them the same general kind of misfortune that they had inflicted on others. The concept of nemesis is summarized in the poet Swinburbe's lines, loosely translating Aeschylus, "For surely as all life is run, Unto him that doeth it shall be done." Some Greek philosophers and historians transformed nemesis from a religious principle into a philosophical or historical one.

*From the Samur Hospital, Vitória da Conquista, Bahia, Brazil. Aceite: 7-março-1997.

Dr. A.H. Chapman - Hospital Samur - Caixa Postal 98 - 45100-000 Vitória da Conquista BA - Brasil. 
In their view it was a law that operated in human affairs in the same way that the principles of physics operate in physical processes.

A nemesis fear is different than a talion fear. In a talion fear a person dreads that he will suffer a physical injury because of hostile feelings or wishes he had against someone. For example, a child who in sibling rivalry had hostile feelings toward, or wished to strike and maim, his brother or sister may later fear that as punishment for this hostility his hand will become crippled. The difference between nemesis and talion fears is the difference between a total life history and an event ${ }^{5}$.

A person with a nemesis fear feels that he or she is being dragged along on a conveyer belt to repeat the painful and perhaps tragic life history of one of his parents. These persons have much anxiety, at times verging on panic, and their nemesis fear often becomes obsessive. Small phobias, mild, fluctuating depression and insomnia may occur. Psychosomatic symptoms such as muscle tension headaches, lack of appetite and vague upper gastrointestinal distress are common. Men and women are equally affected and this problem occurs mainly between the ages of 25 and 50 .

\section{CASE HISTORIES}

Case 1. MGO was a 42-years-old married housewife who had a persistent dread that she would in her early 40 s develop a grave physical illness, probably cancer, and die of it after a long, painful course. She had been reared by a controlling, unaffectionate, strident mother who had many physical complaints. She frequently told the patient that these were caused by the patient's disobedient, careless, untidy behavior. From morning until far into the night her mother laundered and ironed the patient's cloting and endlessly washed other household things "to keep everything clean and orderly". She scrubbed floors, washed walls, polished windows and cleaned kitchen and bathroom fixtures and floors, seeking a perfect cleanliness she never achieved. All this, she said, was because of the patient's messy, recalcitrant ways.

From early childhood onward the patient was deluged with complaints and accusations. "You see these gray hairs?" "You're the one who's putting them there". "If I die before my time it'll be your fault". "You don't care how much I suffer. My back is killing me and my head aches all the time, and it's because of the way you continually mess up everything". She was reared in the acid drizzle of ther mother's guilt-laden tirades and recriminations. Her father was a pharmacist who worked long hours and spent little time at home; he gave the patient little affection and sometimes barked that she "should not upset your mother all the time and make this house the hell it is". The patient married at 18 , more to get away from this painful environment than out of affection for the man she married, and her marriage was drab and tedious. She had 2 children.

When the patient was 27 years old and her mother was 43 her mother died of cancer of the breast after a 1-year painful illness, and the mother's screaming accusations ("Are you satisfied now? This is what you wanted, isn't it?") continued until shortly before her death.

At the age of 41 the patient began to have the conviction that, in retribution for the illness and death of her mother, she would develop a painful illness and die at the age of 43 , as her mother had done. She sought relief in religion but did not find it there. She told no one of her fear, feeling that, in a magical way, the act of putting these things into words would hasten their occurrence. About 7 months before her forty-third birthday she became so upset that she told her husband and sought psychiatric consultation with us.

Case 2. SOR was a 36-year-old woman whose father abandoned her mother when the patient was 3 years old. Her mother remarried when the patient was 5 . When she was 13 years old her stepfather began to make sexual advances to her, and from the age of 14 through 15 she had sexual intercourse on a weekly basis with him. She had orgasms in many of these sexual experience; she felt guilty and apprehensive about this relationship, which both excited and frightened her. Her mother, who had always been a quiet, introspective person, becarne more silent and withdrawn as time went on, and shortly before her sixteenth birthday the patient abruptly realized that her mother had found out about the sexual relationship between her stepfather and herself.

Following this the patient's mother became increasingly disturbed. She developed delusions that her husband and other vaguely identified persons were attempting to kill her. She felt that "dope" was being put in her food and she ate little; she became emaciated and frail. Her mother's relatives finally had her psychiatrically hospitalized and, reluctant to leave an adolescent girl and a man who was not her blood father alone in a house, 
sent her to live with an aunt. After a year of repeated psychiatric hospitalizations and brief, partial remissions her emaciated mother died of pneumonia.

The patient's nemesis fear began when she was 35 . She felt that, to pay the guilty debt she owed her mother, she would become psychiatrically ill and would die psychotic at the age of 36, her mother's age when she died. After 3 months of severe anxiety that verged on panic at times she sought psychiatric help with us despite her dread that seeking such help would be the first step on the way to chronic psychosis and death. She was supported in seeking help by her aunt, the only person in whom she had confided.

Case 3. AVP was a 52-years-old businessman and cattle rancher who came to us with the persistent dread that the would die before he had educated his 4 children and had provided financially for them and his wife. He felt that he must achieve these goals sometime in his early 50s. He did not connect this age with any specific event, but in psychoterapy it became clear that his father had died abruptly of a cardiac infarction at the age of 57. When this occurred the patient was in a chaotic adolescent rebellion against his father. He vehemently advocated leftist radical political views which angered his conservative, well-to-do father. He was failing in school, was associating with people of whom his parents disapproved and by his life style and actions was rejecting everything his father represented. The patient in his nemesis fear felt that he would die suddenly, presumably of heart disease, before his children were established in life. These things, which were easily brought out in psychotherapy, had been unperceived by the patient. He had not connected anything in his past life with his nemesis fear before he entered treatment.

Case 4. LCB was a 27-years-old man who felt that he must crowd the pleasures of a lifetime into the first 35 years of his life because he believed he would not live beyond that age. His parents had been killed in an automobile accident when his father was 38 and his mother was 34 . At that time he was going through a period of school truancy, drug usage and thievery at home and in his father's filling station to get money to buy drugs and other things. In a dim way be had connected his death fears with the deaths of his parents, but the terror this thought caused prevented him from putting it into clear expression either to himself or to others.

Case 5. OFS was a 24-year-old woman who was obsessed with the idea that she must have 2 children by the time she was 24 . She felt that at that age she would become an invalid. In psychoterapy the roots of this fear were found in her mother's gradual incapacitation by multiple sclerosis when she was in her middle 20s; this began shortly after the patient's birth. Several times between the ages of 4 and 10 the patient overheard relatives saying that her mother's illness had been caused by the difficult pregnancy and caesarean section which led to the patient's birth. The patient, who never told anyone these things, felt that she was thus responsible for her mother's neurological illness and would have to pay this debt by duplicating her mother's life. Her mother was still alive, a wheelchair invalid with marked emotional instability and intellectual defects, when the patient developed her nemesis fear. The patient was strongly devoted to her husband and wanted to give him 2 children before she, like her mother, became incapacitated by chronic illness.

Other Cases. We have seen 2 other cases in which nemesis fears were prominent factors in the patient's psychoneurotic illness. Each of these cases is basically similar to one of the 5 cases vignettes presented above.

\section{DISCUSSION}

These 7 patients were seen in 50-minute interviews for from 4 to 43 sessions. The average was 18 interviews. The long distances some of them had to travel to attend psychoterapy were factors in limiting our contacts with 4 of these patients. We feel that we helped all of them, but none of them were completely relieved of their nemesis fears. The terror of theses fears was much reduced but the basic thought, with a certain amount of anxiousness, was not eliminated; it intruded on their awareness from time to time. Medication played a minor role in treatment; it usually was restricted to a bedtime medication when insomnia was a problem.

In treatment these patients experience much relief when they are told that what they are going through is a well defined kind of emotional problem and that the therapist has encountered similar difficulties in other patients. The therapist also emphasizes that it has logical causes that can be discovered in discussions of the life histories of the patients ${ }^{34,6}$.

A nemesis fear is easily overlooked in a psychoneurotic patient. The patient often feels that, in a magical way, putting his or her fear into words will hasten the disaster. This is particularly true when the fear involves chronic psychiatric illness' since the patient fears that revealing his turmoil may precipitate psychiatric hospitalization. 
We have never encountered this problem in a patient over the age of 52 . This suggests that over long periods of time nemesis fears gradually decrease and either disappear or become trivial in middle or old age.

\section{REFERENCES}

1. Cavely RH. Psychiatry is more than a science. Br J Psychiatry 1993;162:154-160.

2. Chapman AH, Vieira e Silva D. Base para uma psiquiatria científica: os conceitos de Harry Stack Sullivan. Arq Neuropsiquiatr 1980;38:1:76-80.

3. Chapman AH, Chapman-Santana M. Handbook of problem-oriented psychoterapy. Northvale NJ, USA: Jason Aronson, in press, Chap 6.

4. James IA, Blackburn IM. Psychotherapy with obsessive compulsive disorder. Br J Psychiatry 1995;166:444-450.

5. Thommen M, Blaser A, Binger C, Heim E. The value of subjective illness theories in problem oriented therapy. Psychother Psychosom Med Psychol 1990;40:172-177.

6. Sullivan HS. Clinical studies in psychiatry. New York: WW Norton, 1956:229-283. 